
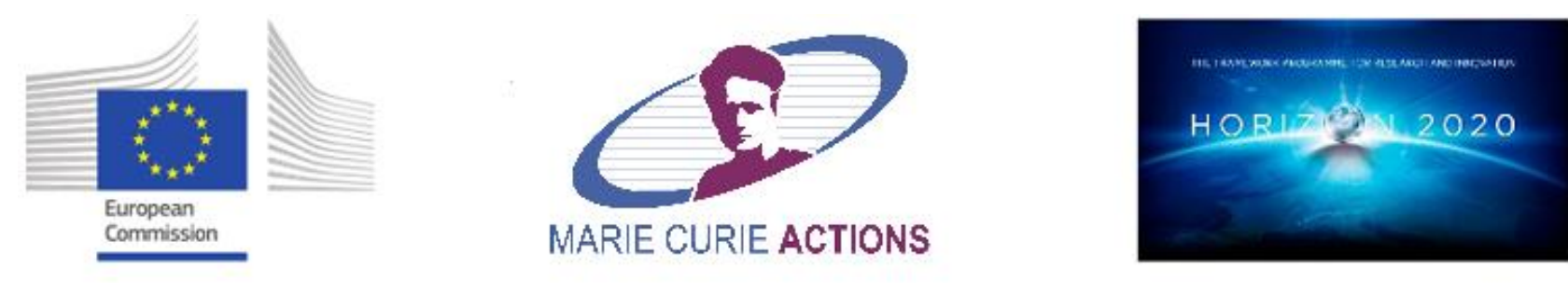

This project has received funding from the European Union's Horizon 2020 research and innovation programme under the Marie Skłodowska-Curie grant agreement No 645704 


\title{
Inverse identification of the bond-slip law for Sisal fibers in High-Performance Cementitious Matrices
}

\section{Identificazione inversa della legge aderenza-scorrimento per fibre di Sisal in matrici cementizie ad alte prestazioni}

\author{
S.R. Ferreira ${ }^{1}$, M. Pepe $^{2}$, E. Martinelli², F.A. Silva ${ }^{3}$, R.D. Toledo Filho ${ }^{1}$ \\ ${ }^{1}$ Civil Engineering Department, COPPE, Federal University of Rio de Janeiro, Rio de Janeiro, Brazil \\ ${ }^{2}$ Department of Civil Engineering, University of Salerno, Fisciano (SA), Italy. \\ ${ }^{3}$ Civil Engineering Department, Pontifical Catholic University of Rio de Janeiro, Rio de Janeiro, Brazil
}

\begin{abstract}
The use of Natural Fibers (NFs) in Fiber-Reinforced Cementitious Composites (FRCCs) is an innovative technical solution, which has been recently employed also in High-Performance FRCCs. However, NFs are generally characterized by complex microstructure and significant heterogeneity, which influence their interaction with cementitious matrices, whose identification requires further advances in the current state of knowledge. This paper presents the results of pull-out tests carried out on sisal fibers embedded in a cementitious mortar. These results are considered for identifying the bond-slip law that describes the interaction between the sisal fibers and the cementitious matrix. A theoretical model, capable of simulating the various stages of a pull-out test, is employed as part of an inverse identification procedure of the bond-slip law. The accuracy of the resulting simulations demonstrates the soundness of the proposed theoretical model for sisal fibers embedded in a cementitious matrix. / L'uso di Fibre Naturali per la realizzazione di compositi a matrice cementizia rappresenta una soluzione tecnica innovativa, recentemente impiegata anche nel caso di compositi ad alte prestazioni. È necessario chiarire, comunque, che dette fibre sono spesso caratterizzate da microstruttura complessa e notevole eterogeneità, aspetti che influenzano la loro interazione con la matrice cementizia e richiedono significativi avanzamenti della conoscenza per interpretarne il comportamento meccanico. Questa memoria presenta i risultati di prove di estrazione (pull-out tests) eseguite su fibre di sisal inserite all'interno di una matrice cementizia. Tali risultati vengono considerati al fine di identificare la legge aderenza-scorrimento che descrive la suddetta interazione tra fibra e matrice. Un modello teorico, capace di simulare le diverse fasi successive che si osservano nelle prove di estrazione, viene impiegato nell'ambito di una procedura di identificazione inversa della suddetta legge. L'accuratezza delle simulazioni condotte tramite la legge identificata su tutte le prove considerate in questo studio conferma la consistenza meccanica del modello utilizzato.
\end{abstract}

KEYWORDS: Sisal Fibers; Fiber Reinforced Cementitious Composites; Bond-slip law; Pull-out test; Inverse identification / Fibre di Sisal; Compositi a matrice cementizia; Legge aderenza-scorrimento; Prove di estrazione; Identificazione inversa.

\section{INTRODUCTION}

In the last decade many researches have been developed with the aim of exploring the potential of composite materials, based on either polymeric or cementitious matrices, internally reinforced by fibers derived by plant leaves or branches (Netravali \& Chabba, 2003). These fibers, generally referred to as either "vegetal" or "natural", highlighted promising properties in terms of both strength (Silva et al. 2010) and durability (Melo Filho et al. 2013, Ferrara et al. 2014; Ferrara et al., 2015). Moreover, they have an apparent potential for enhanced sustainability with respect to similar materials reinforced with industrial fibers made of either steel (Toledo Filho, 1997) or plastic fibers (Sreekumar et al. 2009).

The aforementioned researches unveiled the multifold potential of Natural-Fiber-Reinforced Cementitious Composites in reducing the demand of raw materials, as they are mainly based on using re- newable resources, and the supply and production costs, as the original plants are widely available, especially in tropical and sub-tropical zones.

Among the various Natural Fibers (NFs) investigated so far, those made from sisal (agave sisalana) leaves (Silva et al. 2009) have attracted a great interest in both material scientists and concrete technologists (Netravali \& Chabba, 2003). More specifically, their excellent properties in terms of tensile strength is the main motivation for using them as a reinforcement in composite materials (Silva et al. 2008). However, it should be recognized that the weak chemical bonds that can be established with matrices based on Portland cement results in low mechanical bond between these fibers and matrices, whose maximum strength might be estimated in the range of 0.32 and $0.72 \mathrm{MPa}$, according to experimental results reported in the scientific literature (Silva et al. 2011). Moreover, the high water absorption capacity of sisal fibers results in a volume expansion when 
they are added to the fresh cementitious matrix and, conversely, it produces a contraction when the matrix dries and, hence, a partial detachment between fibers and matrix at the hardened state.

Different procedures have been proposed for reducing water absorption capacity in natural fibers and improving fiber-matrix bond interaction: they are based on applying chemical and physical treatments of both matrix and fibers (Ferraz et al. 2011). For instance, the partial replacement of cement with microsilica have led to increasing the pullout resistance by about 24\% (Toledo Filho, 1997). This increase is related to the fineness of microsilica, which is capable to reduce porosity in the transition zone, hence enhancing the fiber-matrix bond. Furthermore, the use of alkaline solutions (Saha et al. 2010; Kundu et al. 2012) removes most of the surface non-cellulosic substances and increases roughness of their surface, hence enhancing the fibermatrix bond. Simple treatments, such as soaking the fibers in distilled water followed by a drying process, also result in improving the fiber-matrix bond ( $\mathrm{Li}$ et al. 2008). Moreover, a reduction in the fiber hydrophilicity can be achieved by means of wetting and drying cycles promoting hornification (namely, stiffening of the polymeric structure present in lignocellulosic materials, as defined by Claramunt et al., 2010). This treatment promotes a reduction in volumetric changes of pulps and fibers of natural origin, as well as a significant alteration in their mechanical properties, while acting also as a bridge between fibers and cementitious matrices and, hence, strengthening the interfacial bond (Claramunt et al. 2010).

This paper summarizes the results of pull-out tests carried out on hornified sisal fibers embedded in a cementitious mortar. Then, these results are employed in identifying the bond-slip law that describes the interaction between sisal fibers and cementbased matrix: an inverse identification procedure, based on a theoretical model capable of simulating the various stages of a pull-out test, is applied for this task (Ferreira et al. 2016).

\section{EXPERIMENTAL PROGRAM}

\subsection{Materials and processing}

The sisal fibers used in the present study were obtained from sisal plants growing in farms located in the Bahia state, Brazil. They were extracted from the sisal plant leaves in the form of long fiber bundles: this process was executed by means of semiautomatic scrapers.

As regards microstructure, it consists of numerous individual fibers (fiber-cells), which are about 6$30 \mu \mathrm{m}$ in diameter. The individual fiber-cells are linked together by means of the middle lamella. The chemical composition of sisal fibers includes approximately $60.5 \%$ cellulose, $25.7 \%$ hemicellulose,
$12.1 \%$ lignin, $1 \%$ pectin and $1.6 \%$ ash (Fidelis, 2012; Silva et al. 2009; Silva et al. 2010).

The cement-based matrix presented a mix design of 1:0.5:0.4 (binder: sand: water/binder ratio) by weight.

The binder was composed by $30 \%$ of Portland cement CP-32 F II, 30\% of metakaolin and $40 \%$ of fly ash. This ratio of metakaolin and fly ash was aimed to guarantee the durability of the fiber once a matrix free of calcium hydroxide is obtained (Toledo Filho et al. 2009; Melo Filho et al. 2013).

The fly ash also ensured higher workability to the matrix that, within the context of high-performance composites, is a desirable property, as it provided a better homogenization of the natural fibers (Ferreira et al. 2015).

The sand was processed to obtain a maximum diameter of $840 \mu \mathrm{m}$ and the superplasticizer was the Glenium 51 (type PA) with solids content of $31 \%$. In addition, a viscosity modifier Rheomac UW 410, (manufactured by BASF), at a dosage of $0.8 \mathrm{~kg} / \mathrm{m}^{3}$ was also used in order to avoid segregation and bleeding during molding.

The matrix showed a flow table spread value of $450 \mathrm{~mm}$ according to the Brazilian standard NBR 13276 (2005) and a compressive strength at 28 days of $31 \mathrm{MPa}$, according to NBR 7215 (1996).

The mixtures were produced in a room with controlled temperature $\left(21 \pm 1^{\circ} \mathrm{C}\right)$ using a mixer with capacity of 51 . The mixing procedure consisted of the following stages:

- all dry components were homogenized in the mixer;

- the water and superplasticizer were added and mixed for 2 min at a speed of 125 RPM;

- the process was stopped during $30 \mathrm{~s}$ to remove the material retained in the mixer;

- the mixing procedure continued for $2 \mathrm{~min}$ at 220 RPM and, finally, for a further $5 \mathrm{~min}$ at 450 RPM.

A special mold was developed for preparing the specimens. After filling the mold with the matrix, the top cap was fixed and the fiber stretched slightly for alignment. The mortar was placed in plastic bags before being placed in the mold as to facilitate the casting process. Embedment length of 25 was analyzed. After 24 hours, the specimens were demolded and placed in a fog room (HR\% $\geq 95 \%$ ) to moist curing for 7 days for the pullout test.

\subsection{Hornification process}

The sisal fibers were placed in a container with water $\left(\mathrm{T}=22^{\circ} \mathrm{C}\right)$ during three hours to reach its maximum water absorption capacity. The drying process was carried out in a furnace at a temperature of $80^{\circ} \mathrm{C}$. The furnace used was equipped with an elec- 
tronic temperature control and connected to a scale, with a tolerance of $0.01 \mathrm{~g}$ to record the loss of water.

The furnace was programmed to reach $80^{\circ} \mathrm{C}$ at a heating rate of $1^{\circ} \mathrm{C} / \mathrm{min}$ and to maintain this temperature for 16 hours. After 16 hours of drying, the furnace was cooled down to the temperature of $22^{\circ} \mathrm{C}$ in order to avoid possible thermal shock to the fibers. This procedure was repeated ten times. More details can be obtained elsewhere (Ferreira et al. 2015).

\subsection{Testing}

The sisal fiber's microstructure was investigated using a Hitachi TM3000 Scanning Electron Microscope (SEM). The microscope was operated under an accelerating voltage of $15 \mathrm{kV}$. A pre-coating with a thin layer of approximately $20 \mathrm{~nm}$ of gold was done to make the fiber conductive and suitable for analysis. In order to measure the fiber's crosssectional area, for each single fiber used in the pullout and tensile test, an adjacent piece of the fiber (immediately next to the one tested) was kept for future measurement and morphology characterization using the SEM. Fiber-matrix interface zone was also investigated. The obtained images were postprocessed using ImageJ, a Java-based image processing program.

The tensile tests were performed in an electromechanical testing machine Shimadzu AG-X with a load cell of $1 \mathrm{kN}$. The tests were performed on $15 \mathrm{si}-$ sal fibers using a displacement rate of $0.1 \mathrm{~mm} / \mathrm{min}$. The fibers with a gage length of $50 \mathrm{~mm}$ were glued to a paper template for better alignment in the machine and for a better griping with the upper and lower jaws in accordance with ASTM C1557 (2013). To calculate the tensile strength of the fibers, their diameters were measured by image analysis from micrographs obtained in a scanning electron microscope.

The pullout tests were performed in an electromechanical testing machine Shimadzu AG-X with a load cell of $1 \mathrm{kN}$. The tests were carried out using a displacement rate of $0.1 \mathrm{~mm} / \mathrm{min}$. The samples were fixed in the machine grips through a system with hinged-fixed boundary conditions. Fifteen tests were performed (embedded length of $25 \mathrm{~mm}$ ).

\section{ANLYTICAL MODELING}

An analytical model has been formulated for simulating the interaction between fiber and matrix in a pull-out process (Ferreira et al., 2016).

It assumes that:

- the fiber behaves in a linear elastic way;

- the matrix is supposed to be perfectly stiff;
- the interaction between fiber and matrix is based on a bond-slip law $\tau$-s, invariant throughout the fiber length.

As for the last point, the model assumes the following bilinear bond-slip law (Figure 1):

$$
\tau(s)=\left\{\begin{array}{ccc}
k_{e l} \cdot s & \text { if } & |s| \leq s_{e l} \\
\tau_{r}-k_{i n} \cdot\left(s-s_{e l}\right) & \text { if } & s_{e l}<|s| \leq s_{u} \\
0 & \text { if } & |s|>s_{u}
\end{array}\right.
$$

where $k_{e l}=\tau_{\max } / s_{e l}$ is the slip modulus of the elastic branch ending at a slip value $s_{e l}$ with a corresponding bond stress $\tau_{\max }$. Moreover, $\tau_{r}$ is the residual bond stress, and $k_{\text {in }}$ is the post-peak slip modulus, strictly positive in eq. (1), resulting in a linear variation of stresses from $\tau_{r}$ to $\tau_{u}$, the latter being achieved for a slip $s_{u}$.

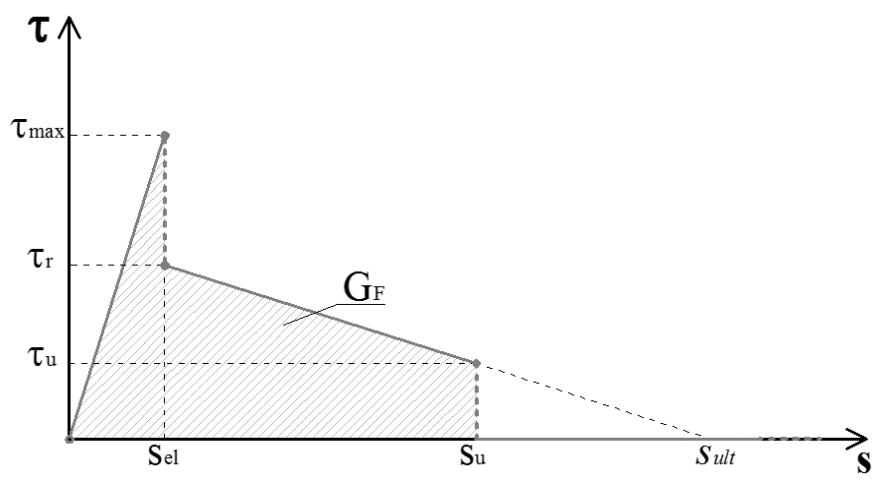

Figure 1. Bilinear bond-slip law / Legge bilineare aderenzascorrimento

The equilibrium equation of an infinitesimal element of fiber can be easily determined as already presented in several models already available in the literature (Caggiano et al. 2012), a general equilibrium condition can be determined (Figure 2):

$$
\frac{d \sigma_{f}}{d z}-\frac{P_{f}}{A_{f}} \cdot \tau=0
$$

Moreover, the axial strain $\varepsilon_{f}$ developing in the fiber is strictly related to the interface slip $s$ :

$$
\varepsilon_{f}=\frac{d s}{d z}
$$

Since the fiber is elastic $\sigma_{f}=E_{f} \varepsilon_{f}$ and, hence, equation (3) can be introduced in eq. (2), in order to obtain a well-known differential relationship between the second derivative of the interface slips and the corresponding bond stress $\tau$ (Caggiano et al. 2012):

$\frac{d^{2} s}{d z^{2}}-\frac{P_{f}}{E_{f} A_{f}} \cdot \tau(s)=0$ 


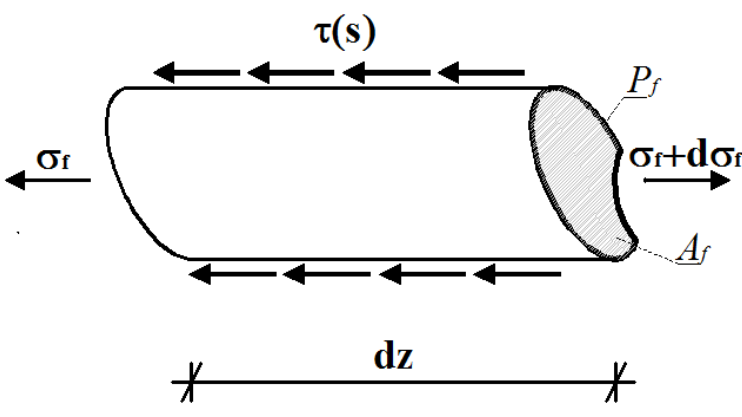

Figure 2. Local equilibrium conditions on a free infinitesimal element of fiber / Condizioni di equilibrio locale su un segmento di fibra di lunghezza infinitesima.

A step-wise analytical solution can be obtained by considering the various states of stresses of the fiberto-matrix interface resulting from the bilinear bondslip law represented in Figure 1. Further details on both the mathematical derivation and the numerical implementation of this solution are available in Ferreira et al (2016).

Based on the above assumptions, the full range analytical expression of the applied pull-out force $F_{0}$ can be, as a function of the displacement $s_{0}$ at the end of the fiber embedment, on the loaded side.

Moreover, $F_{0}$ also depends upon the actual bondslip law assumed for describing the interface behavior. Hence, the following conceptual relationship can be written:

$$
F_{0}=F_{0}\left(s_{0} ; \boldsymbol{q}\right)
$$

where $q$ is a vector that collects the five parameters describing the interface law de-scribed in Figure 1:

$\boldsymbol{q}=\left[\begin{array}{lllll}s_{e l} & s_{u} & \tau_{\max } & \tau_{r} & \tau_{u}\end{array}\right]$

The aforementioned analytical model can be employed for determining the parameters describing the actual bond-slip interaction by means of an "inverse identification" procedure (Martinelli et al. 2012). More specifically, the following optimization problem has to be solved:

$\overline{\boldsymbol{q}}=\underset{\boldsymbol{q}}{\arg \min } \Delta(\boldsymbol{q})$

being

$$
\Delta(\boldsymbol{q})=\sum_{i=1}^{n}\left[F_{0}\left(s_{0, i} ; \boldsymbol{q}\right)-F_{0, i}{ }^{\exp }\right]^{2}
$$

where $s_{0, i}$ is the displacement imposed on the free end of the fiber at the i-th increment of the experimental procedure, $F_{0 \text {,iexp }}$ is the corresponding force and $n$ is the number of displacement increments either in the experimental process or the current numerical analysis.

\section{RESULTS AND ANALYSIS}

\subsection{Morphological characterization of sisal fiber}

Table 1 summarizes the results derived from the SEM analysis by presenting the measured value in terms of area, perimeter and fiber's shape.

Table 1. Sisal fibers geometry / Geometria delle fibre di sisal.

\begin{tabular}{cccc}
\hline \multirow{2}{*}{$\#$} & Area & Perimeter & \multirow{2}{*}{ Shape } \\
\cline { 2 - 3 } & $\mathrm{mm}^{2}$ & $\mathrm{~mm}$ & \\
\hline 1 & 0.01478 & 0.7900 & twisted \\
2 & 0.01739 & 0.8200 & twisted \\
3 & 0.03750 & 1.2300 & twisted \\
4 & 0.01753 & 0.6114 & horse shoe \\
5 & 0.01115 & 0.5619 & twisted \\
6 & 0.02270 & 0.8739 & twisted \\
7 & 0.01650 & 0.5330 & horse shoe \\
8 & 0.01641 & 1.0300 & twisted \\
9 & 0.02970 & 0.8281 & horse shoe \\
10 & 0.01571 & 0.5683 & arch \\
11 & 0.02391 & 1.0600 & twisted \\
mean & 0.02030 & 0.8097 & - \\
\hline
\end{tabular}

Based on the values of parameters reported in Table 1 , the hornified sisal fiber presents high scattering in terms of morphological characterization. The area and perimeter values range from 0.001 to 0.003 $\mathrm{mm}^{2}$ and 0.53 to $1.3 \mathrm{~mm}$, respectively. This significant variation might be directly related to the significant variability in the shape of fibers' cross-sections.

This clue is confirmed by Figure 3, which shows the three typical cross-section shapes exhibited by sisal fibers, each one presenting a different relationship between cross-section area and perimeter.

As a matter of fact, within the leaf, there are three basic types of fibers, generally referred to as structural, arch and xylem fibers (Silva et al., 2011). Structural fibers have a horse shoe shape and a rough surface (Figure 3a); arch shape fibers (Figure $3 b)$ grow in association with the conducting tissues of the plant (usually found in the middle of the leaf); xylem fibers grow opposite to the arch fibers, presenting a twisted shape (Figure 3c), similar to double-helical DNA model. 


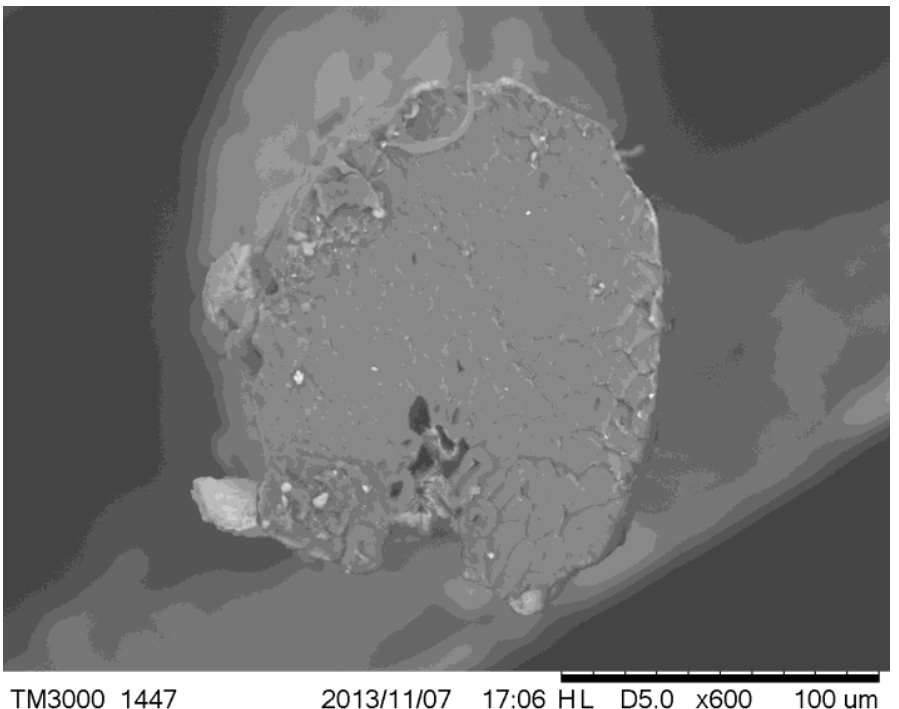

(a)

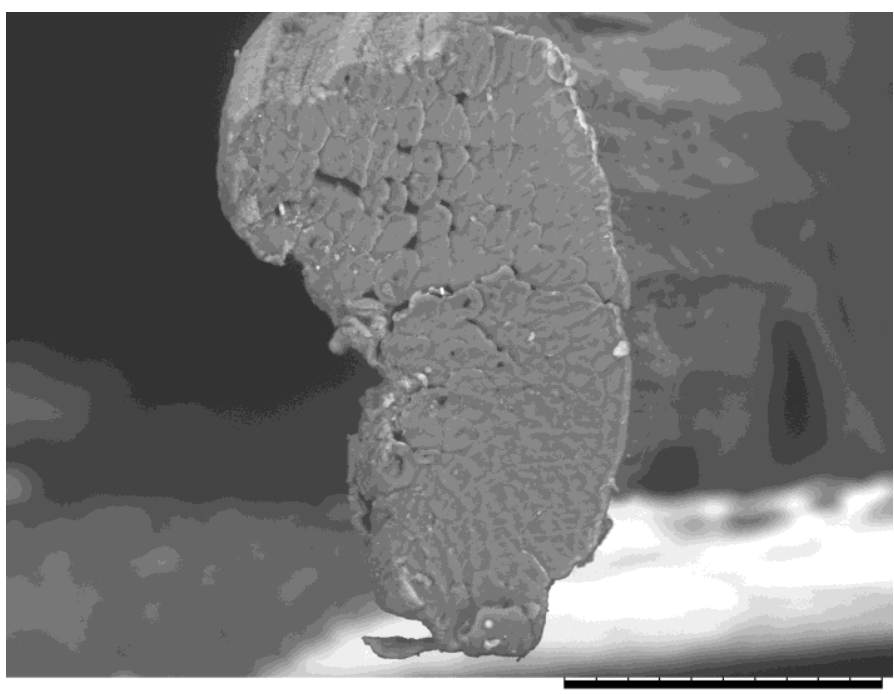

TM3000_1450

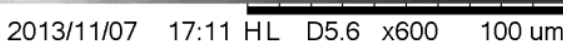

(b)

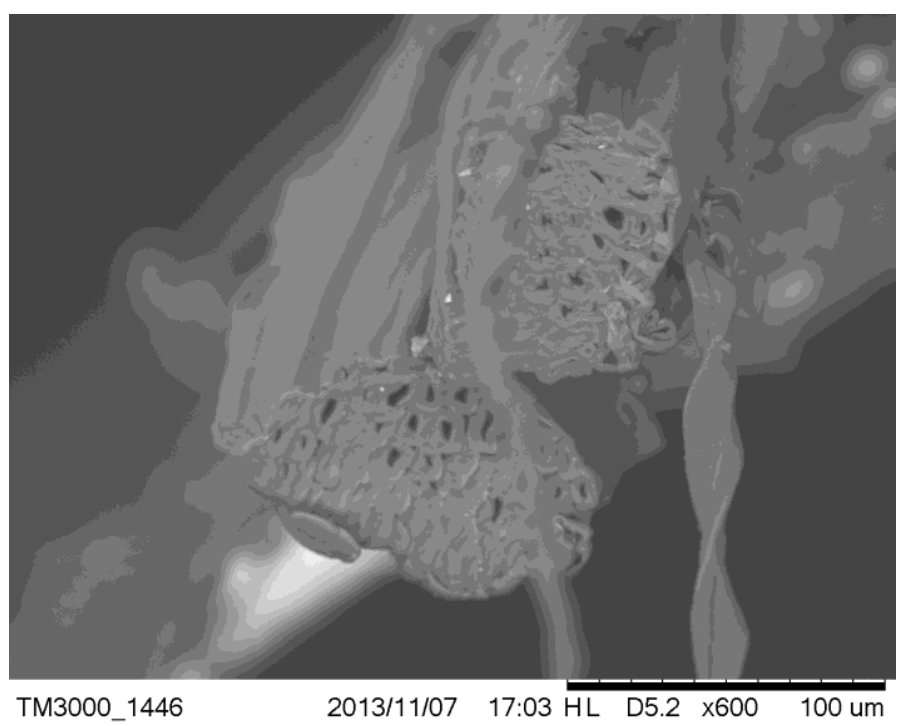

(c)

Figure 3. Sisal fiber shape: horse shoe (a), $\operatorname{arch}(\mathrm{b})$, twisted (c) / Forma delle fibre di sisal: ferro di cavallo (a), arco (b), ritorta (c).

\subsection{Mechanical properties}

The results in terms of tensile strength and the corresponding elastic modulus for both untreated and hornified sisal fibers are summarized in Table 2. They show that hornification induce to a slight increase in tensile strength and strain at failure (about $5 \%$ ), while it reduces the elastic modulus.

In fact, wetting and drying cycles change the microstructure in natural fibers, which, in turn, modifies the polymeric structure of the fiber-cells resulting in higher tensile strength and strain. Moreover, it is worth highlighting that hornification reduces the variability affecting the mechanical response of sisal fibers, both in terms of tensile strength (coefficient of variation slumps from 67 to 26\%) and elastic modulus (CoV reduces from 3.5 to $2.7 \%$ ).

Table 2. Tensile tests results / Risultati delle prove di trazione.

\begin{tabular}{lcccc}
\hline \multirow{2}{*}{ Treatment } & \multicolumn{2}{c}{ Tensile strength } & \multicolumn{2}{c}{ Elastic modulus } \\
\cline { 2 - 5 } & $\mathrm{MPa}$ & $\mathrm{CoV}(\%)$ & $\mathrm{GPa}$ & $\mathrm{CoV}(\%)$ \\
\hline Natural & 453.23 & 66.49 & 20.16 & 3.52 \\
Hornification & 474.86 & 26.46 & 18.05 & 2.75 \\
\hline
\end{tabular}

\subsection{Bond-slip law identification}

The results of the inverse identification of the bondslip laws performed on hornified sisal single fiber pull-out tests, are summarized in Table 3.

Table 3. Parameters of the identified bond-slip law results / Parametri delle leggi aderenza-scorrimento identificate.

\begin{tabular}{ccccccc}
\hline \multirow{2}{*}{$\#$} & \multicolumn{1}{c}{$s_{e}$} & $s_{u}$ & $\tau_{\max }$ & $\tau_{r}$ & $\tau_{u}$ & $G_{F}$ \\
\cline { 2 - 7 } & $\mathrm{mm}$ & $\mathrm{Mm}$ & $\mathrm{MPa}$ & $\mathrm{MPa}$ & $\mathrm{MPa}$ & $\mathrm{Nmm}$ \\
\hline 1 & 0.08 & 2.96 & 0.31 & 0.28 & 0.21 & 0.36 \\
2 & 0.11 & 4.19 & 0.27 & 0.22 & 0.13 & 0.36 \\
3 & 0.50 & 8.05 & 0.14 & 0.13 & 0.09 & 0.41 \\
4 & 0.28 & 5.22 & 0.35 & 0.27 & 0.25 & 0.86 \\
5 & 0.30 & 5.21 & 0.44 & 0.30 & 0.29 & 1.12 \\
6 & 1.57 & 5.76 & 0.27 & 0.13 & 0.02 & 0.53 \\
7 & 1.31 & 5.20 & 0.62 & 0.34 & 0.13 & 1.20 \\
8 & 0.20 & 7.90 & 0.39 & 0.19 & 0.15 & 1.40 \\
9 & 1.00 & 5.55 & 0.15 & 0.12 & 0.08 & 0.30 \\
10 & 0.36 & 3.35 & 0.31 & 0.26 & 0.12 & 0.31 \\
11 & 0.62 & 3.95 & 0.20 & 0.20 & 0.19 & 0.38 \\
mean & 0.58 & 5.21 & 0.31 & 0.22 & 0.15 & 0.66 \\
CoV $(\%)$ & 86.7 & 31.5 & 44.5 & 34.0 & 52.4 & 62.1 \\
\hline
\end{tabular}

A total number of 15 tests were performed (embedded length equal to $25 \mathrm{~mm}$ ), but 4 samples exhibited fiber fracture and for this reason their results are not considered in the present analysis for the bondslip law identification.

The quality of the approximation that can be achieved by means of the proposed model is demonstrated by comparing experimental results and analytical simulations (in terms of $\mathrm{F}_{0}$ - $\mathrm{S}_{0}$ curves) for each test (Figure 4). The curves clearly demonstrate that the analytical solution proposed in this study is capable of accurately reproducing the bond behavior of hornified sisal fibers embedded in a cement matrix. 


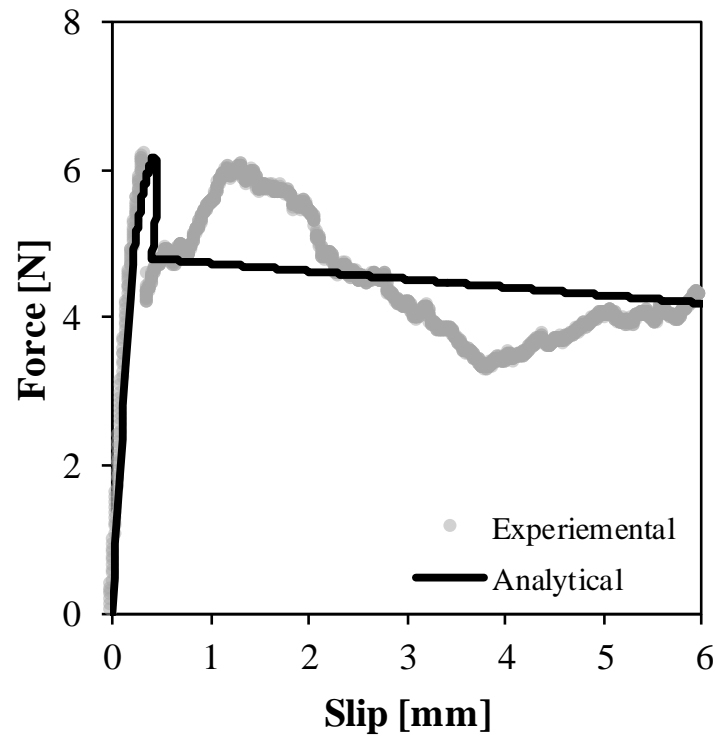

(a)

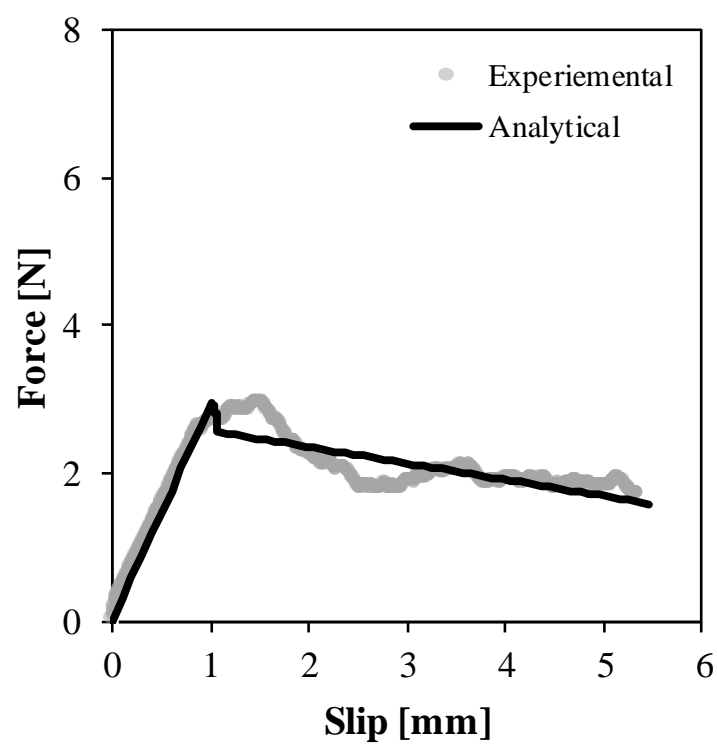

(b)

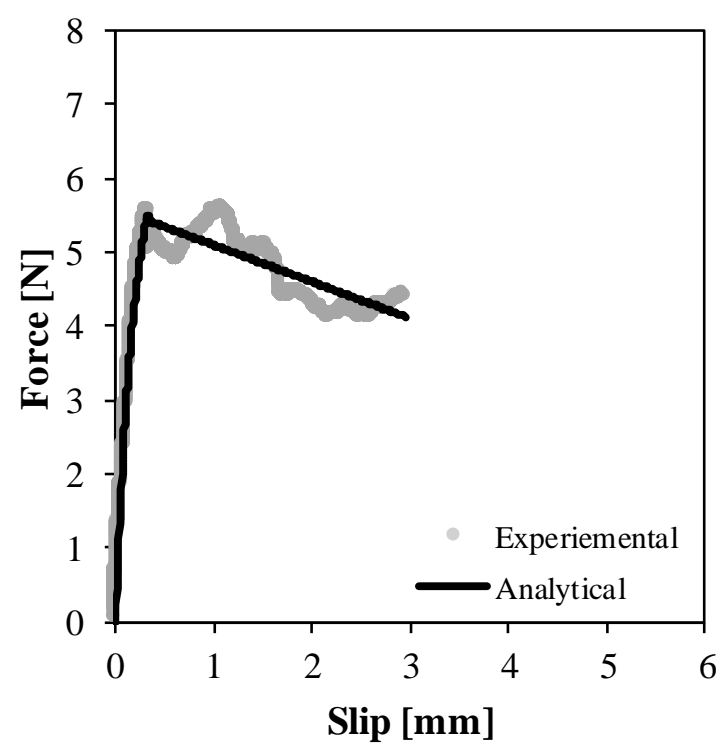

(c)

Figure 4. Simulation examples of the force-slip response / Esempi di simulazione della risposta forza-scorrimento.

However, the results reported in Table 3 highlight that the bond-slip laws identified for the various tests are fairly scattered. In other words, defining a unique bond-slip law capable to describe the bond behavior of natural fibers in cement matrix does not seem realistic. This can be justified by considering that sisal fibers are heterogeneous, in terms of both mechanical and geometric properties, and this heterogeneity leads to a significant variability in the resulting adhesion with mortar. In fact, the resulting bond behavior in cement matrix is influenced by several parameters, such as fiber shape, fiber cross section area variation along the longitudinal axis and surface texture and roughness of the filaments.

Nevertheless, the identified bond-slip laws may be analyzed and compared in terms of some key mechanical parameters, such as the specific fracture energy $\mathrm{G}_{\mathrm{F}}$, which represents the area under the local bond-slip law in Figure 1.

Before commenting into details the results in Table 3 , it should be mentioned that the bond behavior of fibers in cement matrix can be mainly divided in three phases: adhesion, mechanical bond and frictional bond (Naaman, 1999). The first two mainly depends on the chemical compatibility between the fiber and the matrix and the surface texture of the fiber while the latter is, mainly, governed by the geometrical characteristic of the fiber.

Then, the values of $G_{F}$ reported in Table 3 can be interpreted in the light of the above considerations.

As regards fracture energy, it should be noticed that the high dispersion, in terms of coefficient of variation $\mathrm{CoV}$ (around 60\% as highlighted in Table 3 ), presented by the $\mathrm{G}_{\mathrm{F}}$ can be mainly attributed to the morphological characteristics of sisal fibers. In fact, these fibers are characterized by a high variability in terms of transverse section properties $\left(P_{f}\right.$ and $\mathrm{A}_{\mathrm{f}}$ ) as well as in terms of overall straightness and this heterogeneity influence the frictional bond mechanisms that play a fundamental role on the definition of the fracture energy.

Conversely, the values of $\tau_{\max }$ presents a lower value in terms of $\mathrm{CoV}$. This can be explained by considering that the elastic branch is mainly controlled by the adhesion and mechanical bond mechanism occurring between fiber and matrix, both being more related to the chemical adhesion between sisal fiber and cement based matrix, rather than their geometric properties. 
This paper was intended at investigating the bond behavior of hornified sisal fibers embedded in cement-based matrix. On the one hand, the reported experimental results demonstrate the potential of using sisal fibers as spear reinforcement in cementitious composites. On the other hand, the proposed theoretical model leads to scrutinizing the local bond-slip relationship characterizing the interaction between fiber and matrix.

The following main points can be remarked:

- the pull-out tests highlighted good bond properties of hornified sisal fibers: since the majority of specimens failed in debonding, one can reasonably recognize that their transfer length is longer than 25 $\mathrm{mm}$ and, hence, the majority of the tested specimens can be considered for charactering the bond behavior of sisal fibers;

- an analytical model, already formulated by the Authors for similar problems, was extended to the case of hornified fibers by introducing a more general bi-linear bond-slip law, whose characteristic features (e.g. discontinuities and non-zero ultimate stresses) resulted essential in simulating the observed behavior of the fibers under consideration;

- in spite of the significant variability affecting the geometry of fibers, reasonably stable values of the key parameters of the identified bond-slip laws were determined for the various tested specimens. Particularly, the variability of two main parameters, such as bond strength and fracture energy was analyzed.

The results of this study will pave the way towards a comprehensive understanding of the mechanical behavior of cementitious composites reinforced by natural fibers. Particularly, the research will move toward the structural scale by analyzing the response of structural members made of this the materials considered herein. Moreover, the proposed analytical model will be available for identifying the bond-slip laws resulting for other kinds of natural fibers (i.e. jute and curauá) and compare them with the one determined for hornified fibers.
Questa memoria ha proposto un'indagine sulle proprietà di adesione di fibre di sisal pretrattate e matrici cementizie. In primo luogo, i risultati sperimentali, riportati nel lavoro, dimostrano che tali fibre possono essere potenzialmente impiegate in compositi a matrice cementizia e, inoltre, il modello teorico utilizzato ha consentito di identificare in maniera indiretta il legame di aderenza fibra-matrice.

$\mathrm{Al}$ di là di queste considerazioni generali, lo studio presentato consente di rimarcare i seguenti punti:

- le prove di estrazione hanno evidenziato buone proprietà di aderenza per le fibre pretrattate: poiché la maggioranza dei provini ha esibito crisi per sfilamento, si può ragionevolmente assumere che la lunghezza di trasferimento delle fibre risulta maggiore di $25 \mathrm{~mm}$ e, dunque, la maggioranza dei provini può essere considerate in uno studio rivolto all'identificazione delle proprietà di adesione;

- un modello analitico, già formulato dagli Autori per affrontare problemi simili, è stato applicato al caso di fibre pretrattate introducendo una forma più generale di legge tensione-scorrimento, la quale può assumere discontinuità e valori non nulli di tensione ultima;

- nonostante la notevole variabilità delle proprietà geometrica delle fibre, risultati ragionevolmente stabili sono stati ottenuti per i parametri che definiscono la suddetta legge tensione-scorrimento d'interfaccia fibra-matrice: la variabilità di due parametri fondamentali (come l'energia specifica di frattura e la resistenza massima di aderenza) è stata analizzata in maggior dettaglio.

I risultati di questo studio rappresentano un passaggio intermedio verso la comprensione del comportamento meccanico di compositi a matrice cementizia rinforzati con fibre naturali. In particolare, la ricerca si svilupperà verso la scala strutturale tramite l'analisi di membrature realizzate tramite i suddetti materiali. Inoltre, il modello analitico proposto sarà disponibile per la realizzazione di studi simili, intesi ad identificare il comportamento di altre tipologie di fibre naturali (i.e. iuta e curauá) e comparare le prestazioni di queste ultime a quelle ottenute per fibre in sisal pretrattate. 


\section{ACKNOWLEDGEMENTS}

The study is part of SUPERCONCRETE Project (H2020MSCA-RISE-2014, n. 645704): the Authors wish to acknowledge the financial contribution of the EU-funded Horizon 2020 Programme. More specifically, it was partly developed during the mobilities of both Prof. Romildo D. Toledo Filho at the University of Salerno (Italy), and Dr. Marco Pepe at the Federal University of Rio de Janeiro (Brazil).

\section{REFERENCES}

ASTM standard C1557. 2013. Standard Test Method for Tensile Strength and Young's Modulus of Fibers, ASTM International, West Conshohocken, PA.

Caggiano, A., Martinelli, E. \& Faella, C. 2012. A fullyanalytical approach for modelling the response of FRP plates bonded to a brittle substrate. International Journal of Solids and Structures, 49(17): 2291-2300.

Claramunt, J., Ardanuy, M. \& Garcia-Hortal, J.A. 2010. Effect of drying and rewetting cycles on the structure and physicochemical characteristics of softwood fibres for reinforcement of cementitious composites. Carbohydrate Polymers, 79: 200-205.

Ferraz, J.M., Menezzi, C.H.S., Texeira, D.E. \& Martins, S.A. 2011. Effects of treatment of coir fiber and cement/fiber ration on properties of cement-bonded composites. BioResources, 3:3481-3492.

Ferrara, L., Ferreira, S. R., Krelani, V., Silva, F., \& Toledo Filho, R. D. 2014. Effect of natural fibres on the self healing capacity of high performance fibre reinforced cementitious composites. In Proceedings SHCC3, 3rd international RILEM conference on strain hardening cementitious composites: $9-16$.

Ferrara, L., Ferreira, S. R., Krelani, V., della Torre, M., Silva, F., \& Toledo Filho, R. D. 2015. Natural Fibres As Promoters Of Autogeneous Healing In HPFRCCS: Results From On-Going Brazil-Italy Cooperation. Special Publication, 305, 11-1.

Ferreira, S.R., de Andrade Silva, F., Lima, P.R.L. \& Toledo Filho, R.D. 2015. Effect of fiber treatments on the sisal fiber properties and fiber-matrix bond in cement based systems. Construction and Building Materials, 101: 730-740.

Ferreira, S. R., Martinelli, E., Pepe, M., de Andrade Silva, F., \& Toledo Filho, R.D. 2016. Inverse identification of the bond behavior for jute fibers in cementitious matrix. Composites Part B: Engineering, 95: 440-452.

Fidelis, M.E.A. 2012. Development and Mechanical Characterization of Jute Textile Reinforced Concrete (Doctoral Thesis), Civil Engineering Department, Universidade Federal do Rio de Janeiro (COPPE/UFRJ), in Portuguese.

Kundu, S.P., Chakraborty, S., Roy, A., Adhikari, B. \& Majumber, S.B. 2012. Chemically modified jute fibre reinforced non-pressure (NP) concrete pipes with improved mechanical properties. Construction and Building Materials, 37:841-850.

Li, Y., Hu, C., Yu, Y. 2008. Interfacial studies of sisal fiber reinforced high density polyethylene (HDPE) composites. Composites Part A: Applied Science and Manufacturing, 4:570-578.

Martinelli, E., Napoli, A., Nunziata, B., \& Realfonzo, R. 2012. Inverse identification of a bearing-stress-interface-slip rela- tionship in mechanically fastened FRP laminates. Composite Structures, 94(8): 2548-2560.

Melo Filho, J.A., Silva, F.A., Toledo Filho, R.D. 2013. Degradation kinetics and aging mechanisms on sisal fiber cement composite systems. Cement and Concrete Composites, 40: 30-39.

Naaman, A.E. 1999. Fibers with slip-hardening bond. In: PRO 6: 3rd International RILEM workshop on High Performance Fiber Reinforced Cement Composites (HPFRCC 3): 371-385.

NBR 13276. 2005. Mortars applied on walls and ceilings Preparation of mortar for unit masonry and rendering with standard consistence index. ABNT, Rio de Janeiro.

NBR 7215. 1996. Portland cement - Determination of compressive strength, ABNT, Rio de Janeiro.

Netravali, A.N. \& Chabba, S. 2003. Composites get greener. Materials Today, 6: 22-29.

Saha, P., Manna, S., Chowdhury, S.R., Sen, R., Roy, D. \& Adhikari B. 2010. Enhancement of tensile strength of lignocellulosic jute fibres by alkali-steam treatment. Bioresources Technology, 101: 3182-3187.

Silva, F.A., Chawla, N. \& Toledo Filho, R.D. 2008. Tensile behavior of high performance natural (sisal) fibers. Composites Science and technology, 68:3438-3443.

Silva, F.A., Mobasher, B., Soranakom, C. \& Toledo Filho, R.D. 2011. Effect of fiber shape and morphology on interfacial bond and cracking behaviors of sisal fiber cement based composites. Cement and Concrete Composites, 33:814-823.

Silva, F.A., Mobasher, B. \& Toledo Filho, R.D. 2009. Cracking mechanisms in durable sisal reinforced cement composites. Cement and Concrete Composites, 31:721-730.

Silva, F.A., Toledo Filho, R.D., Melo Filho, F.A. \& Fairbairn E.M.R. 2010. Physical and mechanical properties of durable sisal fiber cement composites. Construction and building materials, 24:777-785.

Sreekumar, P.A., Thomas, S.P., Saiter, J.M., Joseph, K., Unnikrishnan, G. \& Sabu, T. 2009. Effect of fiber surface modification on the mechanical and water absorption characteristics of sisal/polyester composites fabricated by resin transfer molding. Composites Part A: Applied Science and Manufacturing, 40:1777-1784.

Toledo Filho, R.D. 1997. Materiais compósitos reforçados com fibras naturais: caracterização experimental. Doctoral thesis, Civil Enginnering Department, PUC-Rio, Rio de Janeiro, Brazil (in portuguese).

Toledo Filho, R.D., Silva, F.A., Melho Filho, J.A. \& Fairbairn, E.M.R. 2009. Durability of compression molded sisal fiber reinforced mortar laminates. Construction and building materials, 23:2409-2420. 